\title{
Awakening the Architectural Experience: how to Teach the Dialogical Knowledge of Architects
}

\author{
Saura-Carulla, Magda ${ }^{a}$; Muntañola-Thornberg, Josep ${ }^{b}$; Beltran-Borràs, Júlia ${ }^{c}$; Méndez- \\ Rodriguez, Sergi ${ }^{d}$ \\ a Departament Projectes Arquitectònics, Universitat Politècnica de Catalunya. magdalena.saura@upc.edu; \\ ${ }^{\mathrm{b}}$ Departament Projectes Arquitectònics, Universitat Politècnica de Catalunya. jose.muntanola@upc.edu \\ ${ }^{c}$ Departament Projectes Arquitectònics, Universitat Politècnica de Catalunya. julsbel@gmail.com \\ ${ }^{d}$ Departament Projectes Arquitectonics, Universitat Politècnica de Catalunya. smndz84@gmail.com
}

\begin{abstract}
Learning processes in architecture have always been a complex and difficult research field; the specific qualities of architectural education from childhood to adulthood are far from to be really known.

We will present some studies, some coming from works with children in primary school and some from the university level in the school of architecture in Barcelona. We will analyze with some examples how the dialogical dimensions of the knowledge of architects can be developed, underdeveloped and even destroyed in education.

Some conclusions will intend to uncover how to bridge the gap between practice and theory in architectural education, and then we can immediately understand that this gap has been produced by the wrong assumption that learning and design architectural processes can develop out of their social and cultural-geographic circumstances, in an abstract and apolitical place, where the relationships between experience and reflection can never exist.
\end{abstract}

Keywords: Architectural Education, Social Cognition, Environmental Design 


\section{The Kernel of Architectural Learning}

The accelerated development of research in natural, social or cognitive sciences confirms today the truth of these pre-scientific hypotheses. Hundreds of books and works have uncovered, step by step, the specific knowledge of that "architectonic wisdom", throughout different disciplinary views. Some of these views are the following:

A) The negative and interactive relationship between the environment and the living organisms uncovered by Jean Piaget and others. (Piaget, 1980)

B) The heterochronic third developmental power of life, besides the genetic heritage and the survival of species defined by McNamara (McKinney \& McNamara, 1991) and Langer (Langer, Rivera, Schlesinger, \& Wakeley, 2003) and all the ecological essential environmental studies from the last fifty years.

C) The dialogical and chronotopic nature of the human culture and human communication (Bakhtin, The Dialogic Imagination. Four Essays by M.M. Bakhtin, 1981; Hutchins, 2006; Sisto, 2015)

D) The psychosocial historical origin of geometry stated by E. Husserl and uncovered by Derrida (Husserl, 1962).

E) The configurative human structure of cities according to Bill Hillier (1996; 2014).

F) The hermeneutic and phenomenological role of architects analyzed by Paul Ricoeur, and others (Ricoeur, 1985; 1986; Kaufmann, 1995; Giedion, 1975) partially developed today by Pallasma and S. Holl (Pallasmaa, Holl, \& Puente, 2006; Robinson \& Pallasmaa, 2015; Pallasmaa, Mallgrave, Robinson, \& Gallese, 2015).

G) The linguistic dimensions of space defined by Ch. Alexander, B. Hillier and D. Seamon by looking to a set of intersubjective spatial and temporal rules (Alexander, Ishikawa, \& Silverstein, 1977; Hillier \& Hanson, 1984; Seamon, 2008).

$\mathrm{H})$ The mathematical and logical models related with the first cognitive stages of children minds (Piaget, Henriques, \& Ascher, 2013; Zimmermann \& Hofkirchner, 2009).

I) The intersubjective constitutive component of the human distributive spatialanthropological knowledge by E. T. Hall (1959; 1966), E. Hutchins (2006) and others, (Gärdenfors, 2007), (Rapoport, 2008), Gallagher (De Jaeger, Di Paolo, \& Gallagher, 2010), etc.

J) The intersubjective meaning of architecture as art analyzed, among others by the members of the Wanburg Institute, as L. Ettlinguer or E. Gombrich, and by S. Kostof, S. Giedion, M. Saura, etc.

K) Finally the huge work by my friend Lewis Mumford and all his friends like Bruno Zevi, in urban planning, who followed the traces of Patrick Geddes that today have been developed by Alberto Magnaghi(Magnaghi, 2011) and followers: Marcelo Zárate, Raffaele Paloscia, Maurizio Carta, etc.

Diagram I shows the kernel of the architectural knowledge in order to perform a good design as a synthesis of all these previous research works. Two combined pair of conditions, the two axes in this diagram, frames this knowledge: the experience to theory feedback and the subject to social interactions. 
The generation of a good design happens always at the centre of the diagram where the definition of a creative design relies (Saura et alt. 2016). Besides, diagram II shows the relationships between urban planning and education during the twentieth century A.C. (Muntañola and alt, 2014). These relationships are not arbitrary or by chance, they describe a necessary condition of planning as an educative and cultural condition of human life.

In both cases knowledge is generated by interactions between subjects and historical context, between objects and contexts etc. No knowledge is produced by an isolated subject or by an isolated object.

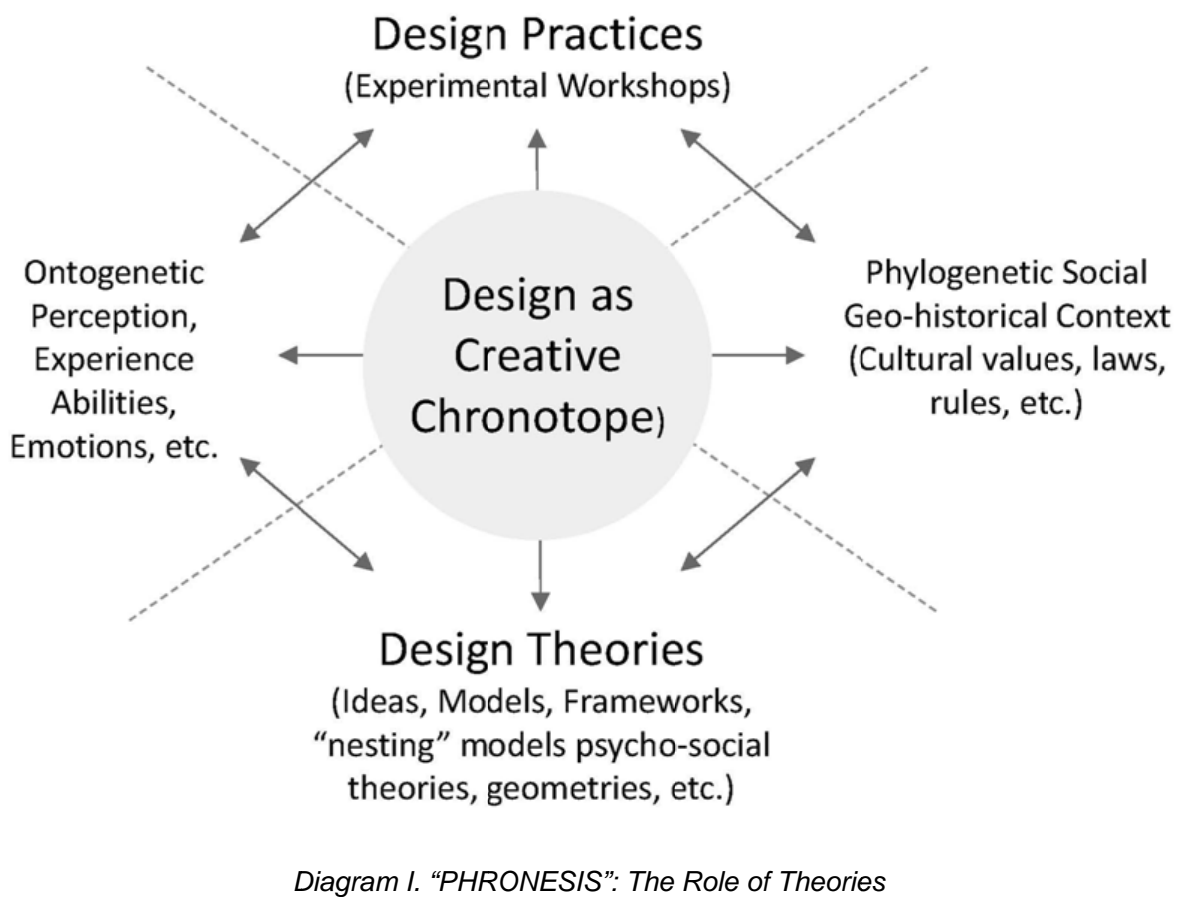




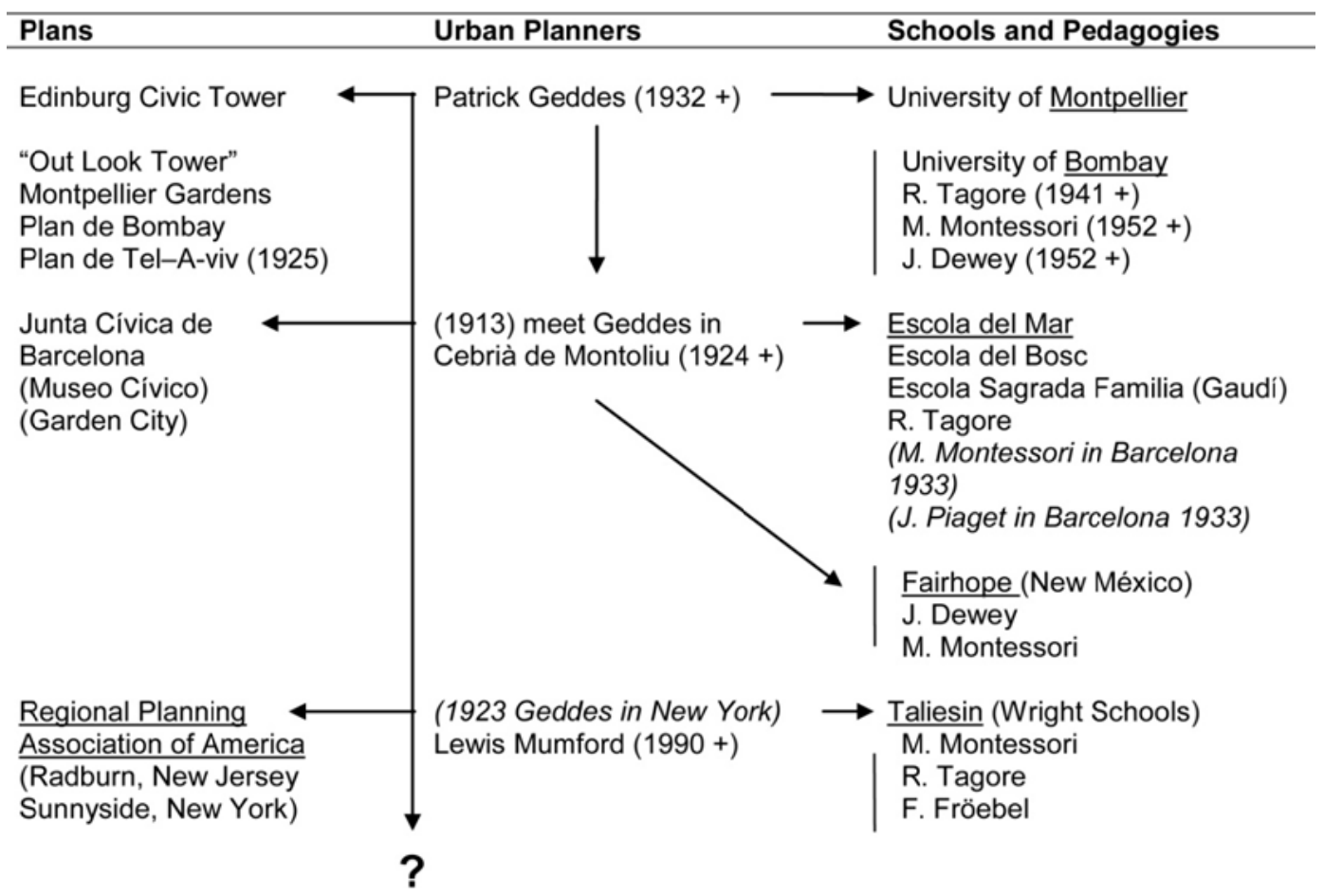

Diagram II. Pedagogical Theories and Urban Planning Theories

\section{The Dialogical Models of Cities Built by Children}

After several studies about the psychogenetic development of children's conceptions of places to live in (Muntañola, 2016a), we started to analyse the construction (or co-construction) of cities by social groups of six children, three boys and three girls, from five to twelve years of age.

These models of cities are dialogical because they "represent" the sociophysical structures you can find in diagram III and IV, where the differences between the monological cities and the dialogical cities are uncovered. Moreover, the cultural characteristics of the schools that "produce" monological or dialogical "spatiality" are shown.

In short, the dialogical cities demands a pedagogy of social cooperation, coordination or, at least, some kind of social interactive and intersubjective sociophysical learning processes.

In contrast, monological cities demand schools with either a high "competitive" input between children or a lack of cooperative intersubjective actions, where each child is working mentally alone. Both, wild children -children that live socially isolated in the natural environment- and virtual addicted children -children that live socially isolated in the real environment-, produce a monological spatiality with lack of social interaction.

Finally, monological fundamentalism produces monological global rigid cities with homogeneous rules.

Moreover these dialogical models are, as Mikhail Bakhtin indicates, "creative chronotopes" (Muntañola, 2016b). They are at a crossing point between:

a) Social interaction and object interaction. 
b) Psychogenetic development and sociogenetic development, since they represent the articulation of personal and social knowledge throughout participation.

c) The new city represented by the model and the real world where the model can be built.

Then, these cities are a beautiful example of "social art" and a good way of understanding the relationship between physical forms and social behaviour.

In this way, the fundamental link between the social interaction of each place and the physical characteristics of this same place are defined, and it is possible to measure it. As Bill Hillier has extensively discussed there exist general forces behind the specific cultural and sociophysical link of each place. However, these forces are at the core of human evolution, so they evolve historically and behave in the way John Searle describes them as background.

They are neither "natural", nor "mechanical". They are the human construction of reality and children know them very well.

In diagrams III and IV some examples of architectural education in children are shown, and the different learning processes are linked to different pedagogies and to different social experiences. So no neutral and magic geometrical forms are the origin of architectural knowledge. Changes in geometry are linked to changes in the social experiences of spatial and temporal frames. Experience and abstractions built together the specific architecture and urban forms generated by six children in each collective construction. (Saura and alt, 2013)

The analysis, by the space syntax digital software of these models of cities built by children, allows to see the physical difference between cities in relation to the social behaviour and use of them. That is the socio-physical structure or configuration of the architecture of the cities defined by Bill Hillier, where the red colour represents the highest social interaction, and the blue the lowest. (Hillier, 1996, 2014)

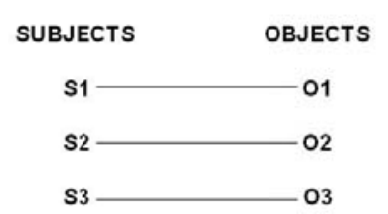

Views and voices are independent

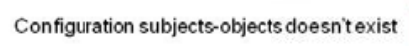

The physical space and time, and social space an time, are only related at individual space
level.

No correlation between subject and object relations. The rules of objects and subjects are not interdependent

Objects and subjects are context-free
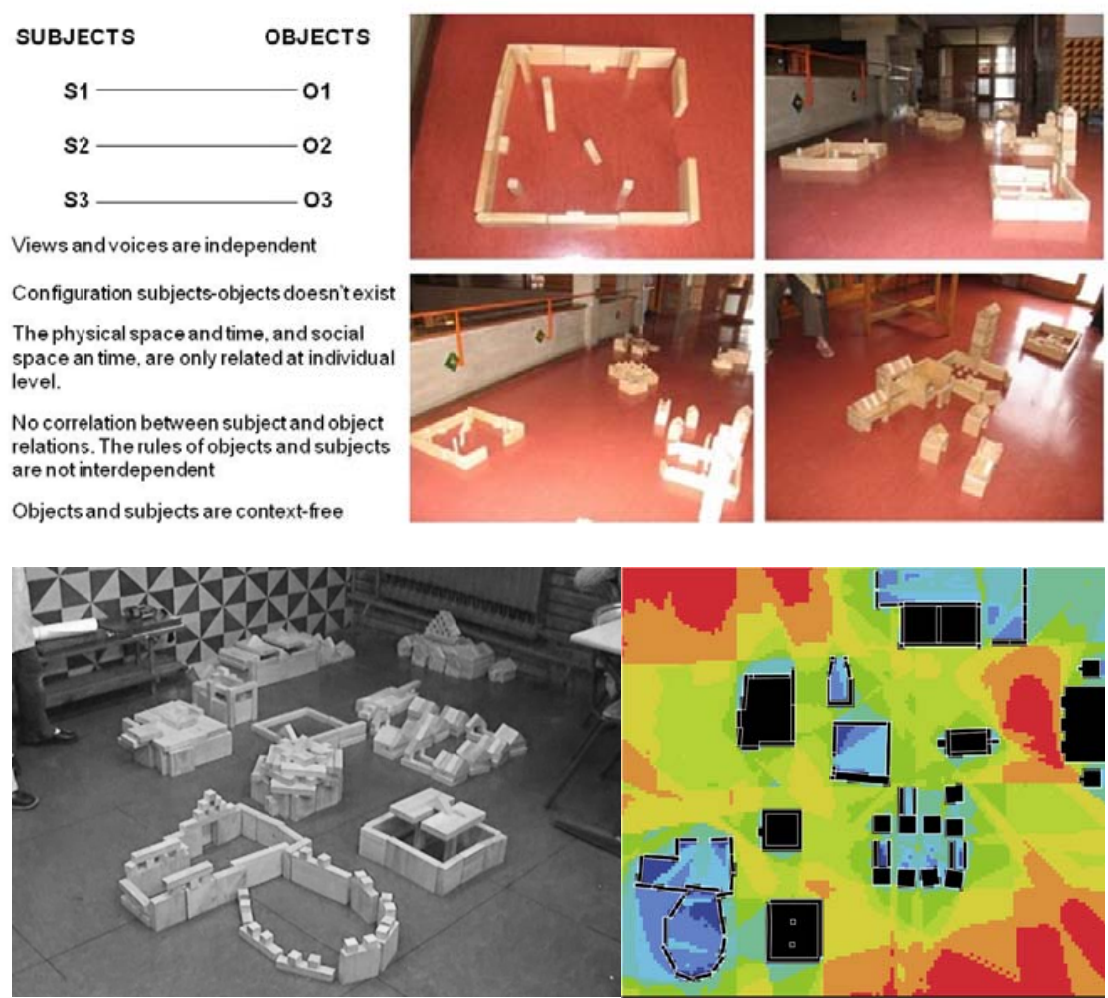

Diagram III. Monological Cities 


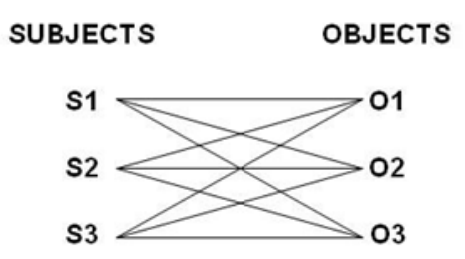

Views and voices related

Configuration exists between subjects/objects

Physical-Social space chronotopically related with time

The rules of objects and subjects are interdependent

Subject and object form a context
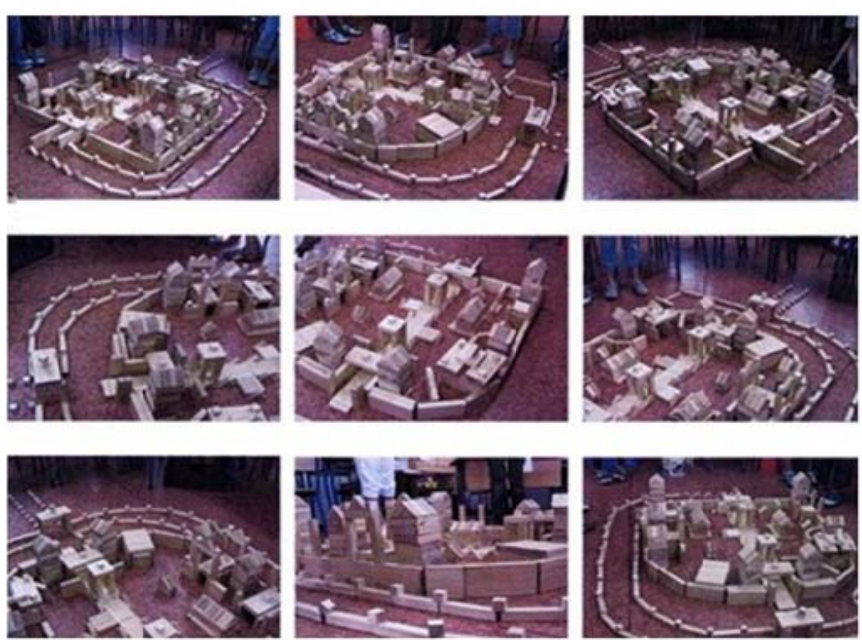
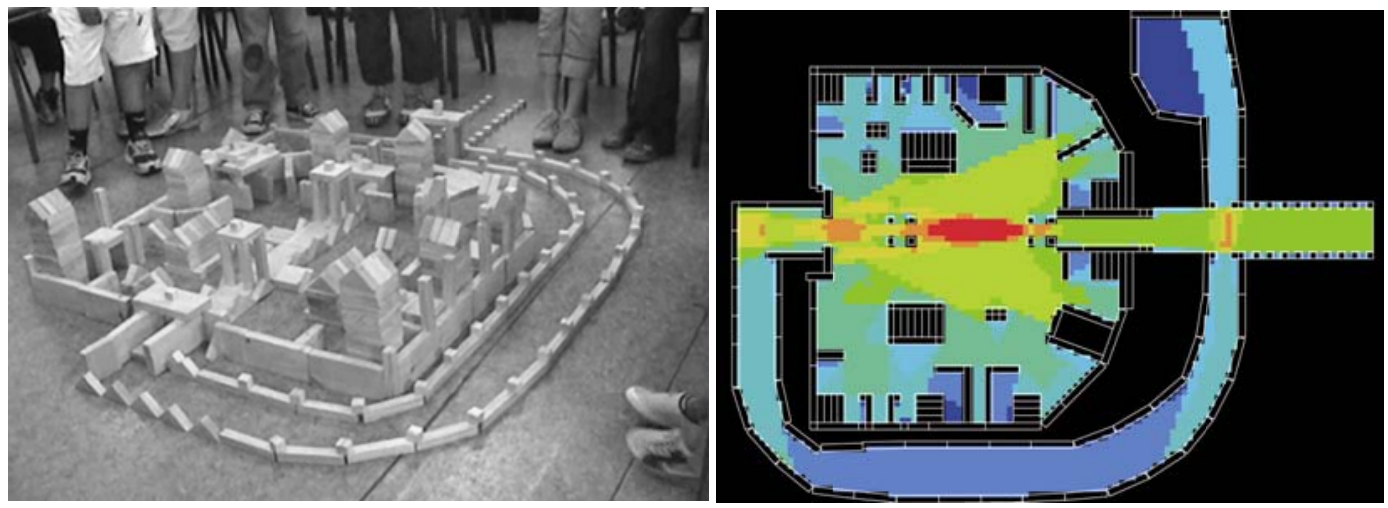

Diagram IV. Dialogical Cities

\section{Some Examples in the School of Architecture of Barcelona}

We will analyse now a micro-experience in the first course of the school of architecture in Barcelona where the professor Magda Saura organised the course with two different previous conditions:

A) The interaction between the design by computer and the design experience of each student is the key point. This feed-back "feeds" the quality of each design, neither the experience of the student, nor the abilities with the computer by themselves "feeds" the quality of each design.

B) The design work is mainly personal, but the permanent social and collective evaluation of the design processes, with the role of the professor as a choreographer who leaves each student to "dance" (to design) as a participant in a cultural and architectural "celebration" or party, is very important too.

In the following figures and written arguments, some students from this first course of architectural design are shown. In each case the interaction between manual experience and computer design is the key of the learning design process. The better is the link between manual abilities and computer abstraction the better is the design at the end. If you analyse this interaction in the best grades, you see that experience and aesthetic artistic qualities combined 
with reflexion through geometric abstractions arrive to good design and in lower grades, either the experience or the abstractions are poorly related, and do not fit each other.

At the end of the studies the final design presented in Mallorca by student Arabella García, it is easy to grasp the control of different representations by hand and by computer, and the increased power of the design thanks to this polyphonic integration of interactive architectural knowledge between the old and the new, the natural and the technical, always in a living spatial place where each object has the best possible location in relation to others. (Muntañola et alt, 2016)

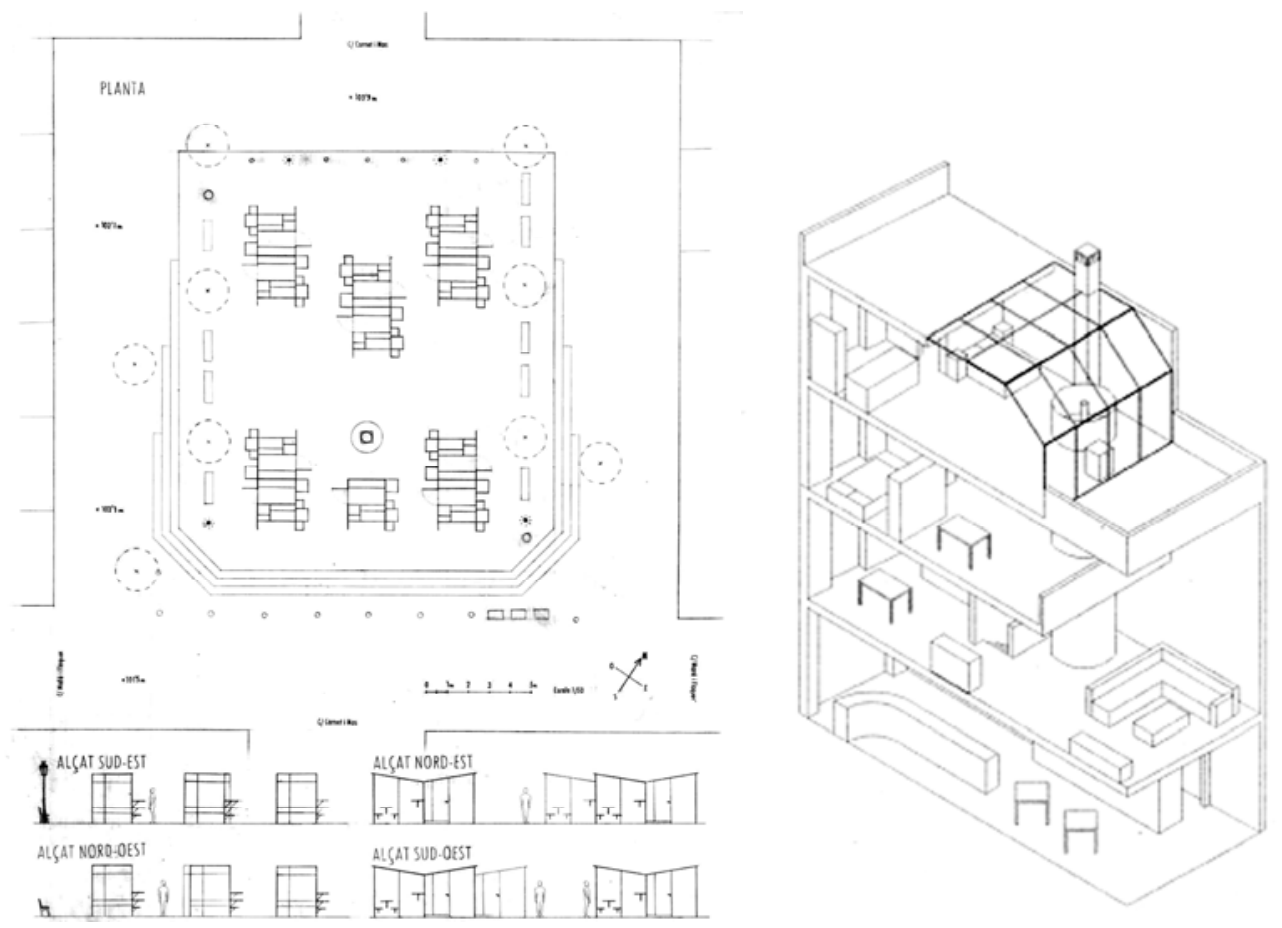

Figure 1. This is the best student in the group; take into account that is the first course of architectural design. He combines abstract geometrical spatial thought with a growing experience about living architectural forms. He never forgets this link, so the real construction of the design is present in the geometrical forms. Models help in the process and artistic references shows that the synthesis between experience and abstraction is there. 


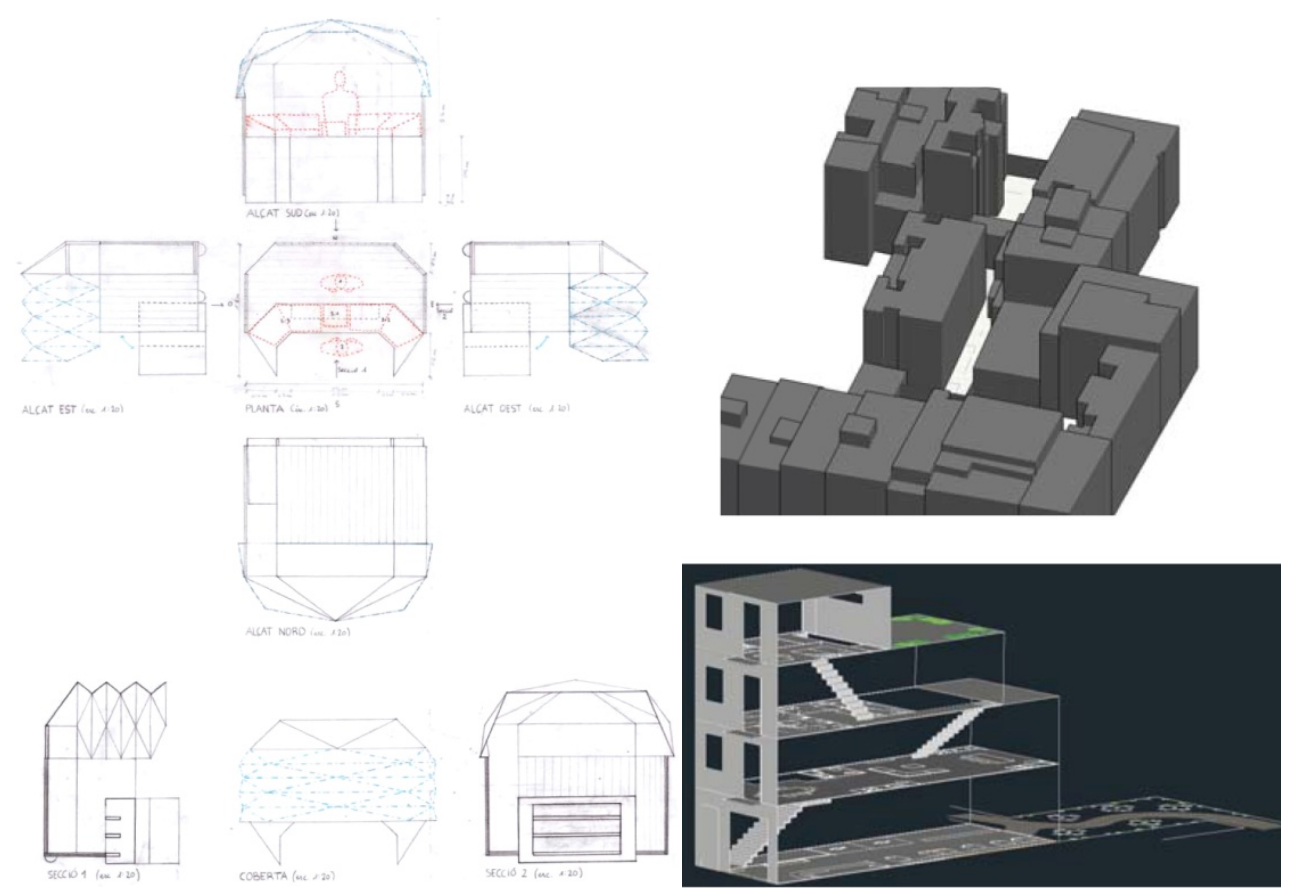

Figure 2. This was a good student; however the extreme need for abstract representation, too soon, decreases her manual qualities. The student cannot control the real qualities of architecture, because she is looking for a better abstraction, but she cannot succeed. And the computer instead to help her pushes her to a less significant design. Probably, with more manual representation the design would be better in her case.

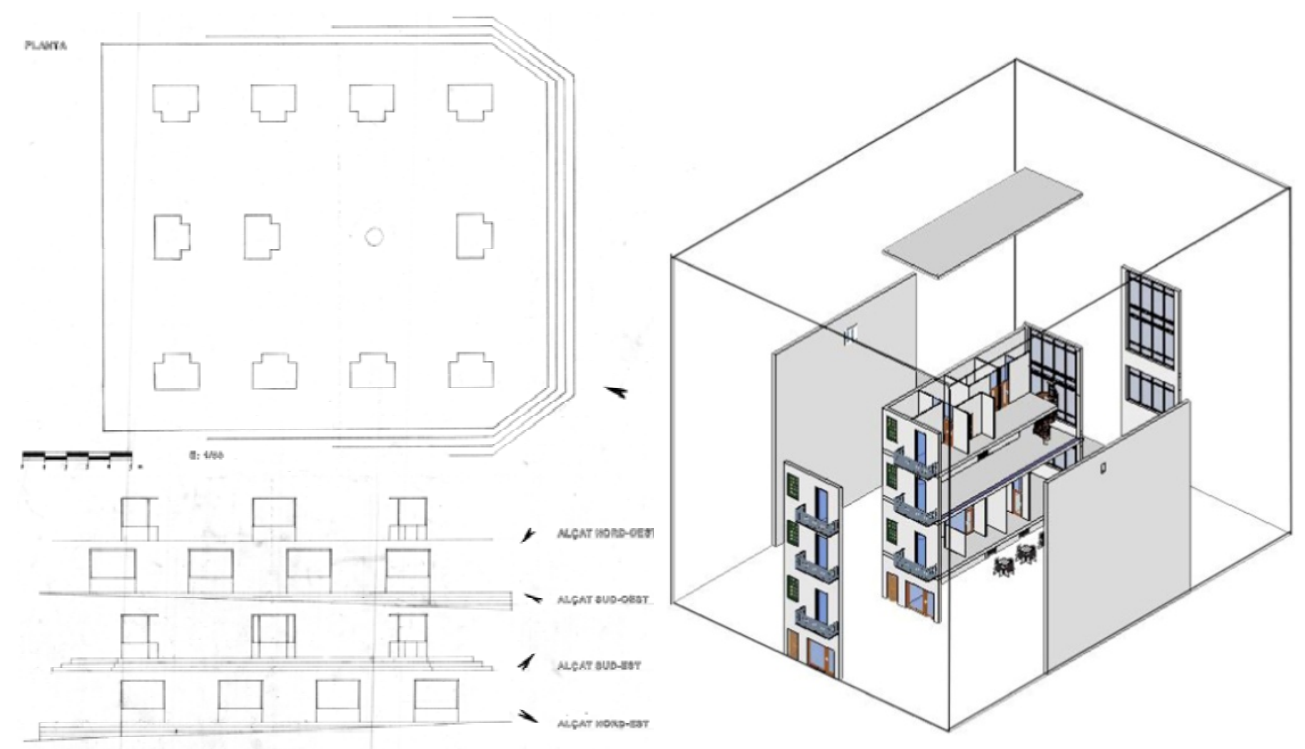

Figure 3. One of the worst students in the group, she is poor both in experience and in abstraction, but she is bad in the link between both. Reason for this performance in her case should be looked for in the horizontal axis of diagram III She is a student with little interaction with the rest of students. The psycho-social poor interaction is often the origin of a lack of link between experience and abstraction, because probably in that case, this link does not follow the social and cultural rules of the group as a social group. The relationships with the children examples in diagrams III and IV are at this point very relevant. 


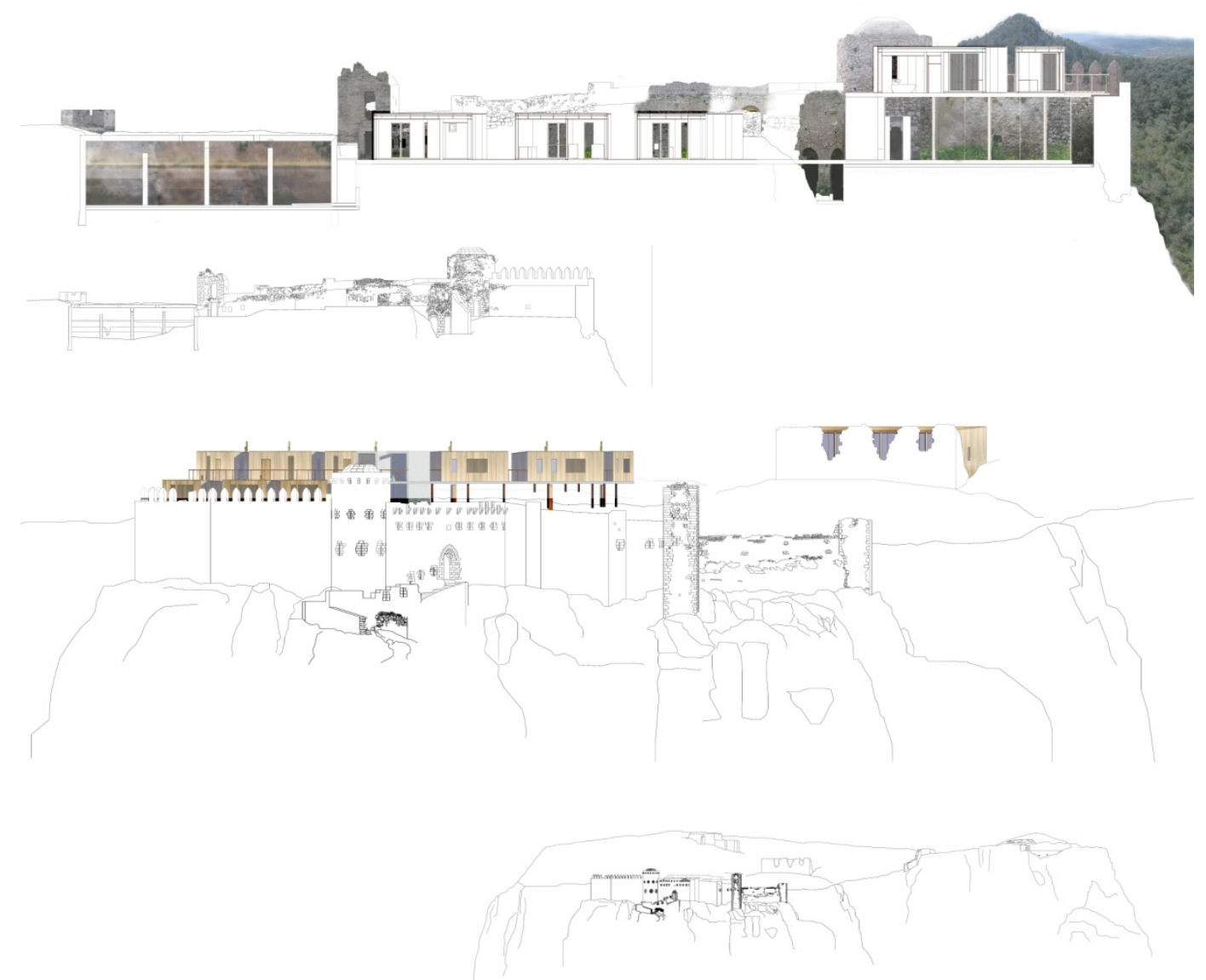

Figure 4. One of the best Final Designs in the last years, this student combined reality a representation in a beautiful and technological manner. The castle of Santueri in Mallorca, today without function, could really be a very special touristic place, with this design. The qualities of the place are kept and the new building follows technic codes and social needs for this kind of expensive touristic locations. Nothing is arbitrary or abstract utopia, real experience is always there, physical and social qualities of architecture never are independent each other, but articulated.

\section{Final Conclusions}

In all the cases presented here, diagram I works as a generative method for architectural teaching and learning. No genetic conditions, and no a-priori rules, can be effective at this point.

The interactions described in the diagram I can fail for a lot of different reasons and we have analysed some of them in the previous chapter. Each student is a specific case of more or less failure and more or less successful interaction, and the role of the professor is just to increase success and decrease failure, however it is the student itself who should take responsibility for his or her design actions.

For this reasons, the choreographic concept is very strong, as the recent work by professors Rainer Zimmermann from Berlin (Zimmermann, 2015) and professor Alva Noe (Noë, 2015) from Berkeley uncover.

The basic idea by Aristotle that in order to teach architecture it is not enough to be able to do good design, because it is necessary to know why that design is good in order to communicate knowledge, is confirmed at this point, since the crossing point between the two axis of diagram I it is not simply a matter of practice but a matter of theory too. However, practice can never be substituted by theories of any kind; it is the interaction between them that generates knowledge. 
Finally, this analysis of architectural design teaching and learning, points to equilibrium in the profession of the architect between practice and theory. Today architectural research is considered less important than architectural design practices, and, in a long term, this disequilibrium can decrease the power of the profession. (Muntañola, 2016)

\section{References}

ALEXANDER, C., ISHIKAWA, S., \& SILVERSTEIN, M. (1977). A Pattern Language: Towns. Building. Construction (Vol. 2). (J. G. Beramendi, Trans.) New York: Oxford University Press.

BAKHTIN, M. (1981). The Dialogic Imagination. Four Essays by M.M. Bakhtin. (M. Holquist, Ed., C. Emerson, \& M. Holquist, Trans.) Austin: University of Texas Press.

DE JAEGER, H., DI PAOLO, E., \& GALLAGHER, S. (2010). Can social interaction constitute social cognition? Trends in Cognitive Sciences , 14 (10), 441-447.

GÄRDENFORS, P. (2007). Evolutionary and developmental aspects of intersubjectivity. Consciousness transitions: phylogenetic, ontogenetic and physiological aspects , 281-305.

GIEDION, S. (1975). La arquitectura, fenómeno de transición: Las tres edades del espacio en arquitectura. Barcelona: Gustavo Gili.

HALL, E. T. (1966). The Hidden Dimension. London: Bodley Head.

HALL, E. T. (1959). The silent language. New York: Doubleday.

HILLIER, B. (1996). Space is the Machine: A configurational theory of Architecture. Cambridge: Cambridge University Press.

HILLIER, B. (2014). Space syntax as a method and as a theory. ISUF - 21st International Seminar on Urban Form. Porto.

HILLIER, B., \& Hanson, J. (1984). The Social Logic of Space. Cambridge: Cambridge University Press.

HUSSERL, E. (1962). L'origine de la géométrie. Presses universitaires de France.

HUTCHINS, E. (2006). The Distributed Cognition Perspective on Human Interaction. In N. Enfield, \& S. Levinson (Eds.), Roots of Human Sociality: Culture, Cognition and Interaction (pp. 375- 398). Bloomsbury Academic.

KAUFMANN, P. (1995). Qu'est-ce Qu'un civilisé? Cahors, France: Atelier Alpha.

LANGER, J., RIVERA, S., SCHLESINGER, M., \& WAKELEY, A. (2003). Early Cognitive Development: Ontogeny and Phylogeny. In J. Valsiner, \& K. Connolly (Eds.), Handbook of Development and Psychology (pp. 141-172). London: Sage.

MAGNAGHI, A. (2011). El Proyecto Local: Hacia una conciencia del lugar. Arquitectonics: Mind, Land \& Society (Vol. 23). Barcelona: Iniciativa Digital Politècnica.

MCKINNEY, M. L., \& MCNAMARA, K. J. (1991). Heterochrony. US: Springer.

MUNTAÑOLA, J., \& SAURA, M. (2014). On the search of a lost modern planning: Throughout the legacy of Lewis Mumford. Scienza del Territorio, 2, 433-444.

MUNTAÑOLA, J., SAURA, M., MÉNDEZ, S., \& BELTRAN, J. (2016). De la Educación del Arquitecto a la Arquitectura de la Educación: Un diálogo imprescindible. Bordon, 165-180.

MUNTAÑOLA THORNBERG, J. (2016). Arquitectura y Modernidad. Suicidio o reactivación. Barcelona: Edicions UPC.

NOË, A. (2015). Strange Tools: Art and Human Nature. New York: McMillan. 
PALLASMAA, J., HOLL, S., \& PUENTE, M. (2006). Los ojos de la piel: la arquitectura y los sentidos .Gustavo Gili.

PALLASMAA, J., MALLGRAVE, H. F., ROBINSON, S., \& GALLESE, V. (2015). Architecture and Empathy.(P. Tidwell, Ed.) A Tapio Wirkkala-Rut Bryk Design Reader.

PIAGET, J. (1980). Adaptación vital y psicología de la inteligencia. Siglo XXI de España Editores.

PIAGET, J., HENRIQUES, G., \& ASCHER, E. (2013). Morphisms and categories: Comparing and transforming. Psychology Press.

RAPOPORT, A. (2008). Mind, Land and Society Relationships in an Environment-Behavior Perspective. Arquitectonics: Mind, Land \& Society (Vol. 15). Barcelona: Edicions UPC.

RICOEUR, P. (1986). Du texte a l'action. Paris: Seuil.

RICOEUR, P. (1985). Temps et récit. Paris: Seuil.

SAURA CARULLA, M., MUNTAÑOLA THORNBERG, J., BELTRAN BORRÀS, J., MÉNEDEZ RODRÍGUEZ, S., \& MENDOZA KAPLAN, L. (2016). Representar y proyectar arquitecuturas en la era digital. Representing and Designing Architecture in the Digital Era. EGA. Revista de expresión gráfica arquitectónica.

SAURA, M., MUNTAÑOLA, J., \& JORDÁN, A. (2013). Architectural Education 2012: Prospects and Keepings. En Architecture and Education. Arquitectonics: Mind, Land \& Society (Vol. 25, págs. 11-30).

SEAMON, D. (2008). Understanding and Making Places in the City: Integrating the Urban Visions of Christopher Alexander and Bill Hillier. Interdisciplinary Design and Research e-Journal , 2:Design and Livability.

SISTO, V. (2015). Bajtín y lo Social: Hacia la Actividad Dialógica Heteroglósica. Athenea Digital ,15 (1), 329.

ZIMMERMANN, R. (2015). The metaphisics of Emergence. Part 1: On the Foundations of Systems. Berlin: Xonomoi. Verlak.

ZIMMERMANN, R., \& Hofkirchner, W. (2009). The Topos of Virtuality. TripleC: Cognition, Communication, Co-operation , 7 (1), 74-87. 